\title{
Conceptual approach to the assessment of economic security of economic entities on the example of transport enterprises
}

\author{
Elena Karanina ${ }^{1, *}$, Olesya Ryazanova ${ }^{1}$ and Natalia Gritsuk ${ }^{1}$ \\ ${ }^{1}$ Vyatka State University, Preobrazhenskaya St., 41, 610020 Kirov, Russia
}

\begin{abstract}
The article is devoted to the assessment of economic security of economic entities of the territories on the example of transport enterprises of the Kirov region. The purpose of the study is to test the methods of assessing the level of economic security of economic entities in the sphere of transport based on objective and clear criteria and indicators of potential and risk. Methods of the research: economic analysis, integral analysis, averages, ranking, cluster analysis. The first part of the article deals with the economic security of economic entities. The role of transport enterprises in its provision is revealed. In the second part of the article, the methodology of the research is considered. Here the main threats to the activities of transport enterprises and indicators of economic security are outlined. The author's model of the concept of economic security assessment of economic entities of the territories is presented. Key indicators for rating economic safety of economic entities of the territories are considered. In the third part of the article, the results of an assessment of the level of economic security of economic entities of the Territories on the example of transport enterprises of the Kirov region are presented. Clusters of transport enterprises are selected on the basis of indicators of potential and risk. The analysis of threats and risks of economic entities of the territories is carried out. Much attention is paid to the analysis of the social and economic potential of the Kirov region, strengthening its economic security.
\end{abstract}

\section{Introduction}

The state, development and sustainable dynamics of economic entities significantly affect the economic security of the state and territory. Economic entities operate under uncertainty. This is enshrined in the civil legislation of Russia. The state defines entrepreneurial activity as "an independent activity carried out at its own risk. The purpose of the activity is the systematic receipt of profit from the use of property, the sale of goods, the performance of work or the provision of services "[1].

Theoretical study of the essence and content of economic security of economic entities must begin with a study of its definition. Modern economists do not have a single approach to the definition of the term in question. Some authors associate the notion of "economic security of economic entities" with a combination of opportunities and abilities to effectively

\footnotetext{
* Corresponding author: kafinanc@yandex.ru
} 
use the resources of the business entity to ensure sustainability, prevent threats, stable operation and business development. Others - with the state of protection of the enterprise, its capital and resources from various threats.

Elements of economic security are [2]: financial security, security of marketing activities, protection of trade secrets, and confidentiality of information, personnel security, technical, and information security, security of contractual activities, computer security.

Financial security (in the general composition of elements) is the main characteristic of the economic potential of the economic entity. It is necessary to ensure the operation of the enterprise with the necessary resources in the process of achieving its goals.

The financial security of an economic entity is characterized by the stability of the economic development of the enterprise, ensuring and maintaining the necessary level of liquidity and financial independence, the ability to neutralize the negative effects of crisis phenomena, the high quality of the accounting system for financial flows and the effectiveness of the monitoring system. Economic security of economic entities of the territory largely determines the economic security of the territory itself. Commercial enterprises form the backbone of the territory's economy. They are the driver of economic growth.

Transport is a special sphere of material production and an independent branch of the national economy. With its help, communications are carried out within and between industries, within and between economic regions and interstate relations are being formed. The transport complex is the largest part of the infrastructure. It serves as the material and technical basis for the formation and development of the territorial division of labor, has a significant impact on the dynamism and effectiveness of socio-economic development of individual regions and the country as a whole.

Thus, transport enterprises are an integral system-forming element of the territory's economy. They are included in the economic complex both of the country as a whole, and of a separately taken region or territory. Consequently, the issue of assessing the economic security of economic entities of the territories on the example of transport enterprises is very relevant.

\section{Materials and Methods}

Business depends on numerous external (economic, political, organizational, etc.) and internal (financial and non-financial) factors. They form threats. Define the main factors that determine the level of economic security of economic entities of the territories (Fig. 1).

The presence of factors that carry threats to the economic security of economic entities raises the question of assessing its level for timely warning of the danger, mitigating and taking the necessary measures of protection and countermeasures.

To assess how risky or safe that or an economic entity, a scientifically based tool is required. These are methods based on a system of criteria and indicators for assessing economic security. They allow you to form ratings based on the results of their diagnosis. Methods of diagnosing economic security are [2]:

1) Indicative analysis;

2) The method of calculating the integral index;

3) The valuation method, based on the calculation of relative financial indicators and the dynamics of their changes;

4) A method based on the assessment of the consequences of security threats through the definition of material damage.

"In recent years, such scientists as G.P. Andreev, T.B. Bogdanov, B.A. Volkova, N.N. Gromov, R.A. Kozhevnikov, E.F. Kosichenko, B.M. Lapidus, Z.P. Mozhokha, P.V. Metelkin, V.A. Persianov, A.N. Pertsev A.V. Parshikov "[3] and others. 
T.V. Bogdanova under the leadership of VA. Persianova proposed calculating an integral indicator for assessing the level of economic security. The system of coefficients is the basis for assessing the level of economic security. These include [3]:

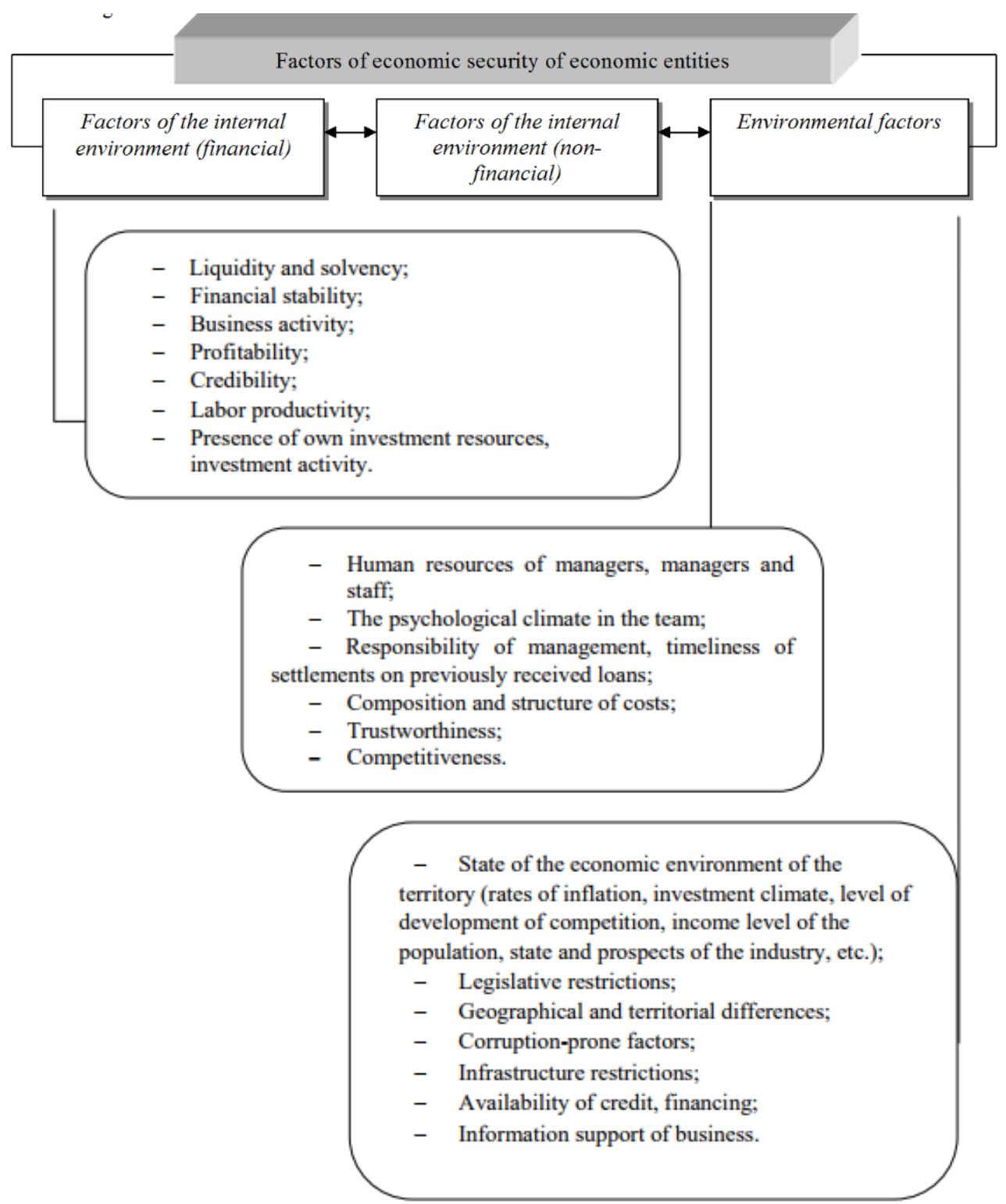

Fig. 1. System of main factors of economic security of economic entities [4].

- $\quad$ coefficient of growth intensity, reflecting the rate of development of the enterprise in comparison with the industry;

- level of depreciation of fixed production assets;

- $\quad$ level of investment;

- $\quad$ financial stability (coverage ratio, the ratio of the security of non-current assets own funds, the coefficient of autonomy);

- $\quad$ coefficient of technical independence; 
- $\quad$ coefficient of staff independence;

- $\quad$ relative market share;

- $\quad$ independence factor of the transport enterprise (from foreign capital).

The calculation of these indicators, in our opinion, cannot always be realized due to the limited information and time. For the rapid diagnosis, we offer a slightly different approach (Fig. 2).

In order to assess the threats and rating of transport enterprises in the economic security system from the point of view of the territorial aspect (using the example of mono-profile municipal entities of the Kirov region), a risk-oriented approach can be applied.

In total, according to official data, 74 transport enterprises operate in 11 mono-profile municipal entities of the Kirov region (as of December 31, 2016) (road transport). They transport goods by specialized and non-specialized vehicles, road freight transport; organize regular interurban and suburban passenger transportation by bus transport, as well as conduct other, supporting activities related to transportation.

The main mode of transport in the territory of the Kirov region is automobile transport, its share in the total volume of transport is $85.8 \%, 11.1 \%$ of the population are transported by trolley buses. As of December 31, 2016, the length of motor roads in the Kirov region is 24,754.1 kilometers, including 55.96 percent hard surface [5]. The share of roads (public use) of federal significance is $1.57 \%$, regional $-10.39 \%$, local $-85.61 \%$; share of non-public roads $-2.43 \%$. According to statistics, the number of goods transported by road from 2000 to 2016 was almost halved. This negatively characterizes the level of development of the economy of the region and the hotel territories. Passenger turnover of public transport buses decreased more than 2.5 times. Part of this fact is due to the increase in the share of private cars. In addition, in many areas of the region there is a situation of depopulation of the population.

In our opinion, an assessment of the level of economic security of transport enterprises can be based on indicators calculated based on public accounting (financial) reporting and information-analytical systems (special paid services). These services act as a tool to reduce commercial risks. Indicators can be divided into two groups [6]:

1 ) indicators characterizing the potential: profitability of sales $(\%)$, return on equity $(\%)$, average number of employees (people), labor productivity (thousand rubles / person), investment activity (thousand rubles / ), coefficient of concentration of own investment resources;

2) Indicators characterizing the level of risk: solvency risk index, reliability risk index, scoring index, liquidity risk index, credit risk, financial advantage ratio [7].

The methodology for assessing the level of economic security of transport enterprises was presented in the article "The Risk-Based Approach to Rating of Competitiveness of Transport Enterprises in the System of Economic Security" [8]. On its basis, the mechanism of cluster diagnostics (rating) of enterprises and territories is being built. It consists in the breakdown of research objects by the parameters of potential and risk into clusters by the method of scoring and determining the integral index of economic security assessment for the ranking of enterprises within the cluster [9].

Based on the allocation of four types of economic entities in the transport sector by potential and three by the level of risk, it is possible to form 12 clusters (Table 1). 


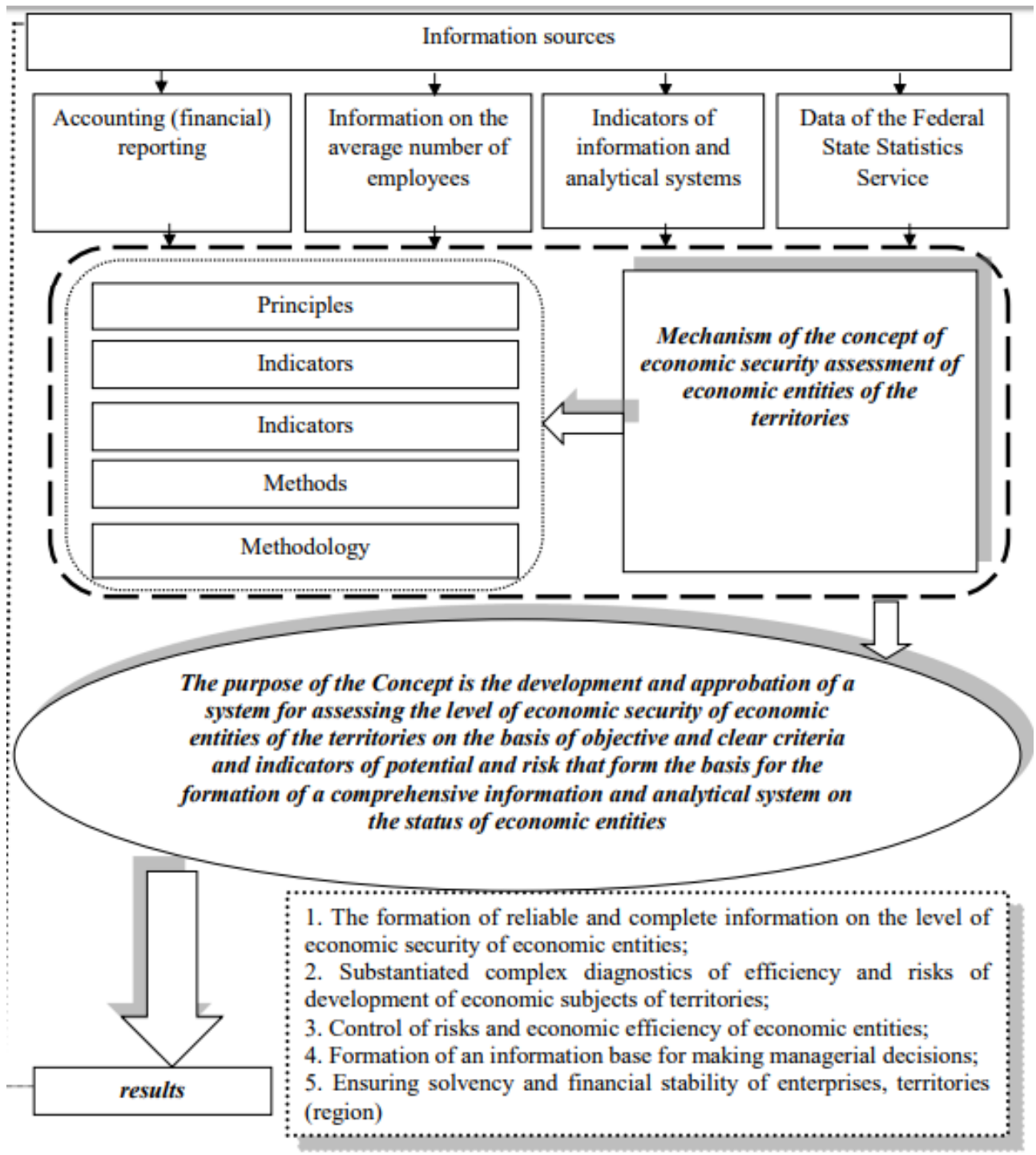

Fig. 2. Author's model of the concept of economic security assessment of economic entities of the territories.

Table 1. Characteristics of the rating of the level of economic security of economic entities.

\begin{tabular}{|c|c|c|l|}
\hline $\begin{array}{c}\text { Item } \\
\text { name }\end{array}$ & Cluster & $\begin{array}{c}\text { Potential-risk } \\
\text { level }\end{array}$ & \multicolumn{1}{c|}{ Economic Security Rating } \\
\hline $\mathrm{Aa}$ & 1 & $\begin{array}{c}\text { High potential- } \\
\text { low risk }\end{array}$ & $\begin{array}{l}\text { The highest rating characterizes the company's ability to } \\
\text { timely and fully fulfill debt obligations, its high solvency, } \\
\text { reliability and competitiveness on the basis of high potential } \\
\text { and efficient work }\end{array}$ \\
\hline $\mathrm{Ab}$ & 2 & $\begin{array}{l}\text { High potential- } \\
\text { moderate risk }\end{array}$ & $\begin{array}{l}\text { The situation and financial condition of the company slightly } \\
\text { differ from Aa's positions, the company is characterized by } \\
\text { high high potential, high capitalization of income with a } \\
\text { moderate level of risk }\end{array}$ \\
\hline $\mathrm{Ac}$ & 3 & $\begin{array}{c}\text { High potential- } \\
\text { high risk }\end{array}$ & $\begin{array}{l}\text { The performance of the company, the state of obligations are } \\
\text { more exposed to the effects of unfavorable changes. The }\end{array}$ \\
\hline
\end{tabular}




\begin{tabular}{|c|c|c|c|}
\hline & & & $\begin{array}{l}\text { company is characterized not only by its high potential, but } \\
\text { also by the high level of risk with respect to timeliness and } \\
\text { completeness of fulfillment of obligations }\end{array}$ \\
\hline $\mathrm{Ba}$ & 4 & $\begin{array}{l}\text { Moderate } \\
\text { potential-low } \\
\text { risk }\end{array}$ & $\begin{array}{l}\text { The rating characterizes the moderate opportunities of } \\
\text { economic entities to maintain high results of production and } \\
\text { financial activities and a high probability of timely and fully } \\
\text { fulfill obligations, low solvency risk. The economic entity is } \\
\text { sensitive to the influence of unfavorable factors or the } \\
\text { environment of functioning }\end{array}$ \\
\hline $\mathrm{Bb}$ & 5 & $\begin{array}{l}\text { Moderate } \\
\text { potential- } \\
\text { moderate risk }\end{array}$ & $\begin{array}{l}\text { The economic entity has moderate opportunities to fulfill its } \\
\text { debt obligations, but the uncertainty of the situation or the } \\
\text { impact of adverse changes in economic and financial } \\
\text { conditions may lead to an inadequate ability of the company } \\
\text { to fulfill its obligations, a temporary decrease in the solvency }\end{array}$ \\
\hline $\mathrm{Bc}$ & 6 & $\begin{array}{l}\text { Moderate } \\
\text { potential-high } \\
\text { risk }\end{array}$ & $\begin{array}{l}\text { At the moment, the company is able in time and in full to } \\
\text { fulfill its obligations to stakeholders, but the unfavorable } \\
\text { development of events may prevent them from fulfilling these } \\
\text { obligations }\end{array}$ \\
\hline $\mathrm{Ca}$ & 7 & Low potential & $\begin{array}{l}\text { The rating characterizes the lowered capacity of the business } \\
\text { entity to maintain high results of production and financial } \\
\text { activity and a high probability of timely and fully meeting } \\
\text { obligations, low solvency risk }\end{array}$ \\
\hline $\mathrm{Cb}$ & 8 & $\begin{array}{l}\text { Lowered } \\
\text { potential- } \\
\text { moderate risk }\end{array}$ & $\begin{array}{l}\text { The economic entity has a reduced potential, but the } \\
\text { uncertainty of the situation or the impact of unfavorable } \\
\text { changes in economic and financial conditions can lead to an } \\
\text { inadequate ability of the company to fulfill its obligations, a } \\
\text { temporary decrease in the solvency }\end{array}$ \\
\hline $\mathrm{Cd}$ & 9 & $\begin{array}{l}\text { Lowered } \\
\text { potential-high } \\
\text { risk }\end{array}$ & $\begin{array}{l}\text { At the current time, there is a potential insolvency of the } \\
\text { company }\end{array}$ \\
\hline $\mathrm{Da}$ & 10 & $\begin{array}{c}\text { Низкий } \\
\text { потенциал- } \\
\text { низкий риск }\end{array}$ & $\begin{array}{l}\text { Timely fulfillment of obligations depends to a large extent on } \\
\text { favorable commercial, financial and production conditions }\end{array}$ \\
\hline $\mathrm{Db}$ & 11 & $\begin{array}{l}\text { Low potential- } \\
\text { moderate risk }\end{array}$ & $\begin{array}{l}\text { The rating reflects the high probability that the company will } \\
\text { not fulfill its obligations to its partners. The company's } \\
\text { position is financially unstable due to its low potential }\end{array}$ \\
\hline $\mathrm{Dc}$ & 12 & $\begin{array}{l}\text { Low potential- } \\
\text { high risk }\end{array}$ & $\begin{array}{l}\text { The rating indicates a critically low performance of the } \\
\text { business entity, a high level of risk, but payments on major } \\
\text { debt obligations have not yet been terminated }\end{array}$ \\
\hline
\end{tabular}

In reality, some clusters may not form in practice. The enterprise cannot successfully function with high potential and at the same time have a high level of risk.

\section{Results}

Calculation, processing of data was carried out with the help of the computer program "Express Diagnostics of Economic Security Indicators of Economic Entities of Territories" [10]. Based on the data obtained (Fig. 3), 37.84\% of enterprises are classified as cluster 4 (moderate potential-low risk), $31.08 \%$ - 5 cluster (moderate potential-moderate risk), $14.86 \%$ - 8 cluster (reduced potential-moderate risk). Thus, more than $70 \%$ of economic entities in the transport sector of the Kirov region's monoterritories have a moderate or decreased potential with a low or moderate level of risk. Cooperation with enterprises of the above clusters is possible. Additional financial resources will allow business entities to strengthen their potential and increase business efficiency. Six enterprises (or $8.11 \%$ ) refer to cluster 11 
(low potential-moderate risk), cooperation with which is possible, but subject to certain conditions and limitations.
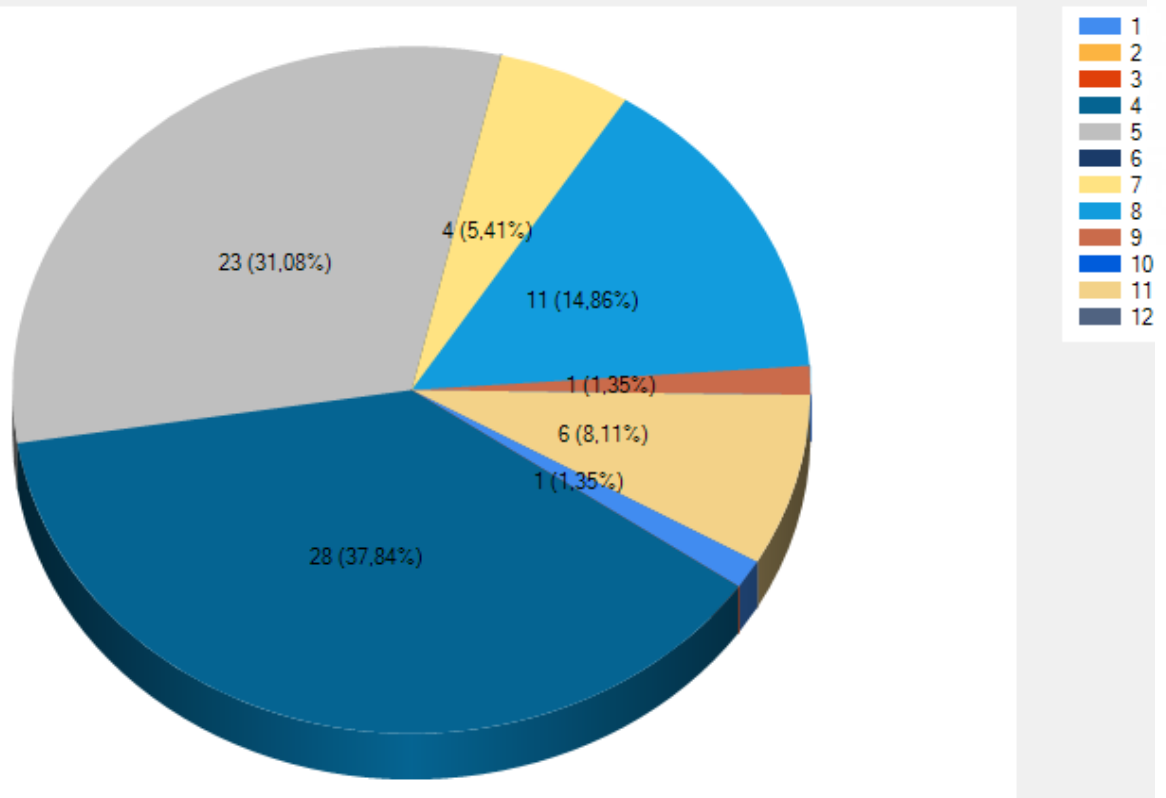

Fig. 3. Distribution of economic entities in the transport sector by clusters in monoterritories of the Kirov region by the scoring method, units, $\%[10]$.

One business entity (1.35\%) joined the 1 cluster, it is a company that fulfills obligations on time in full and on the basis of high potential and efficient work. LLC "Spetstrans", Vyatskie Polyany, belongs to the enterprise of the first cluster.

The main threats for transport enterprises are:

- $\quad$ insufficient labor productivity;

- $\quad$ high level of depreciation of fixed assets;

- low share of own investments;

- $\quad$ high proportion of loss-making enterprises.

\section{Discussion}

The functioning of economic entities in the transport sector has a number of features, including those related to ensuring transport security. In accordance with Federal Law No. 16-FZ dated February 09, 2007 "On transport security", transport infrastructure of transport infrastructure and transport facilities is assigned to the subjects of transport infrastructure [11]. The subjects of transport infrastructure are both municipal entities of the region and carriers. The main problem of ensuring transport security is the lack of funds from the owners of transport infrastructure facilities. In the federal budget, the costs of granting subsidies to subjects of the Russian Federation for carrying out measures to ensure transport security are not envisaged. The study of indicators of the potential and risk of transport enterprises provides an assessment of the real situation and economic security of the territory and the region. Due to the rating evaluation, the state and municipal authorities will be able to channel the necessary forces and resources to develop the economy of the territory (region), provide employment, and ensure economic growth as a whole. Investors (creditors) will be able to 
conduct a preliminary examination of projects in transport enterprises, as their interest consists in a high rate of return on investment (minimum risk of loss of capital), a balance of the investment (credit) portfolio. The society will satisfy with the help of the developed business in the sphere of transport socially significant issues.

Conclusions. Insufficient efficiency of transport enterprises leads to significant losses in the economy of the region. Each region must assess its threats and competitive positions based on its potential and risk indicators. The assessment of economic security of economic entities in the territories is an important element in ensuring the economic security of the entire region. Its assessment will attract the necessary resources to the industry to update the rolling stock of motor vehicles, meet the effective demand and the needs of the population of the Kirov region in the quality public transport services, and create the necessary conditions for safe, convenient and high-quality satisfaction of the residents' needs.

\section{Acknowledgments}

The reported study was funded by RFBR according to the research project 17-02-00179FIRE

\section{References}

1. The Civil Code of the Russian Federation (Part One) of 30.11.1994 N 51-FZ

2. The thesis of the applicant for the degree of candidate of economic sciences on the topic: Development of monitoring of economic security factors of small businesses on the basis of a risk-oriented approach", https://science.volgatech.net/upload/documents/defenceof-eses/diss_RyazanovaOApdf

3. T. Bogdanova, Bulletin of the University (State University of Management), 32-40 (2013)

4. E. Karanina, E. Sapozhnikova, O. Ryazanova, Kirov: Vyatka State University (Vyatka State University, 2017)

5. Federal Service of State Statistics. Official site, http://kirovstat.gks.ru/

6. O. Ryazanova, Innovative development of the economy, 417-421 (2017)

7. Information-analytical system Globas-i. Credinform, http://www.credinform.ru/ruRU/globas

8. O. Ryazanova, E. Karanina, A. Timin, Springer 692, 318-325 (2018)

9. O. Ryazanova, Conf. with intern. Participation, Saint-Petersburg: Polytechnic. Un-t, 465-474 (2017)

10. O.A. Ryazanov, M.A. Kuklin, Svid. 2018614732 Russian Federation. Certificate of state registration of the computer program. Express diagnostics of indicators of economic security of economic subjects of territories №2018612112 (2018)

11. Federal Law of 09.02.2007 N 16-FZ "On Transport Security" (2016) 